\title{
Design, Synthesis and Activity of New Polymyxins ${ }^{\dagger}$
}

\author{
Francesc Rabanal 1,*, Roser Segovia ${ }^{1}$, Aina Coll ${ }^{1}$, Judith Solé ${ }^{1}$, Maria Garcia-Subirats ${ }^{1}$, \\ Angeles Manresa ${ }^{2}$ and Yolanda Cajal ${ }^{3,4}$ \\ 1 Section of Organic Chemistry, Department of Inorganic and Organic Chemistry, Faculty of Chemistry, \\ University of Barcelona, 08007 Barcelona, Spain; roser_sl_92@hotmail.com (R.S.); ainabdn21@gmail.com \\ (A.C.); judsol@outlook.com (J.S.); mgarciasubirats@gmail.com (M.G.-S.) \\ 2 Laboratory of Microbiology, Faculty of Pharmacy, University of Barcelona, 08007 Barcelona, Spain; \\ amanresa@ub.edu \\ 3 Department of Pharmacy, Pharmaceutical Technology and Physical Chemistry, Faculty of Pharmacy and \\ Food Sciences, University of Barcelona, 08028 Barcelona, Spain; ycajal@ub.edu \\ 4 Institute of Nanoscience and Nanotechnology (IN2UB), University of Barcelona, 08028 Barcelona, Spain \\ * Correspondence: frabanal@ub.edu \\ † Presented at the 1st Molecules Medicinal Chemistry Symposium, Barcelona, Spain, 8 September 2017.
}

Published: 20 October 2017

Antibiotic resistance is a daunting challenge for public health systems worldwide. A major goal to fight resistant bacteria involves the design, discovery and development of new antibiotics, particularly against multi-drug-resistant strains. Currently, there is renewed interest in polymyxins, an old class of antimicrobial cyclic lipopeptides, highly potent against therapeutically relevant Gramnegative bacteria. Polymyxins are now used as last resort antibiotics in hospitals because of their nephrotoxicity and neurotoxicity that requires careful monitoring of the patient. Our group has embarked on a project to design and develop new polymyxins devoid of toxicity problems using a versatile and chemically accessible scaffold structure [1,2]. Compounds show excellent activity against Gram-negative bacteria. Synergistic and antibiofilm activities have also been recently described in combination with imipenem [3]. Herein, the latest results of our recently designed polymyxin analogs will be presented.

Acknowledgments: The research was supported by the University of Barcelona, Fundació Bosch i Gimpera, Xarxa de Referència en Biotecnologia, 2016LLAVO0018 grant (Generalitat de Catalunya) and the European Institute of Innovation and Technology (EIT Health). The authors are members of the ENABLE (European Gramnegative Antibacterial Engine) consortium (IMI-ND4BB, http://www.imi.europa.eu/projects-results/projectfactsheets/enable).

Author Contributions: RS, AC, MGS and JS performed research, AM and YC supervised research. FR directed the whole research and writing

Conflicts of Interest: The authors declare no conflicts of interest 


\section{References}

1. Rabanal, F.; Grau-Campistany, A.; Vila-Farrés, X.; González-Linares, J.; Borras, J.M.; Vila, J.; Manresa, A.; Cajal, Y. A bioinspired peptide scaffold with high antibiotic activity and low in vivo toxicity Sci. Rep. 2015, 5, 10558. Available online: https://www.nature.com/articles/srep10558 (accessed on 10 October 2017).

2. Rabanal, F.; Cajal, Y. Recent advances and perspectives in the design and development of polymyxins. Nat. Prod. Rep. 2017, 34, 886.

3. Rudilla, H.; Fusté, E.; Cajal, Y.; Rabanal, F.; Vinuesa, T.; Viñas, M. Synergistic antipseudomonal effects of synthetic peptide AMP38 and carbapenems. Molecules 2016, 21, 1223. Available online: http://www.mdpi.com/1420-3049/21/9/1223 (accessed on 10 October 2017).

(C) 2017 by the authors. Licensee MDPI, Basel, Switzerland. This article is an open access article distributed under the terms and conditions of the Creative Commons Attribution (CC BY) license (http://creativecommons.org/licenses/by/4.0/). 